\title{
PREFERENCE OF QUINOA MOTH: Eurysacca melanocampta MEYRICK (LEPIDOPTERA: GELECHIIDAE) FOR TWO VARIETIES OF QUINOA (Chenopodium quinoa WILLD.) IN OLFACTOMETRY ASSAYS
}

\author{
Juan F. Costa ${ }^{1 *}$, Walter Cosio ${ }^{1}$, Maritza $\operatorname{Cardenas}^{1}$, Erick Yábar ${ }^{1}$, and Ernesto Gianoli ${ }^{2}$
}

\begin{abstract}
Insects are attracted to plants by visual and olfactory cues. The quinoa moth, Eurysacca melanocampta Meyrick (Lepidoptera: Gelechiidae), is the main insect pest of the quinoa crop, Chenopodium quinoa Willd. (Chenopodiales: Chenopodiaceae), in the southern Peruvian Andes, causing grain yield losses. The aim of this study was to investigate the behavioural response of adult quinoa moths to olfactory stimuli. Specifically, the objectives of this study were: 1) to determine the capacity of E. melanocampta adults of searching for quinoa plants using plant olfactory cues; 2) to determine the preference of E. melanocampta females for the odours derived from two varieties of quinoa: Amarilla de Marangani and Blanca de Junín; and 3) to assess the attraction of male quinoa moths to E. melanocampta females and the host plant in olfactometric bioassays. Adults preferred quinoa plant odour sources in choice tests when distilled water was used as a control $(\mathrm{P}<0.0001)$. Females were more attracted to the Blanca de Junín variety than to Amarilla de Marangani variety $(\mathrm{P}<0.05)$. Males were more attracted to the odour derived from females than to the volatile compounds from plants (both varieties) or to the odour blend derived from plants plus females together. The level of attraction of males towards females is negatively affected by the presence of the quinoa plants.
\end{abstract}

Key words: attraction, Chenopodiaceae, Gelechiidae, searching, olfactometry, quinoa.

\section{INTRODUCTION}

Recognition by insects of their host plants is facilitated by different stimuli: visual, olfactory, gustatory and tactile (Bernays and Chapman, 1994). Perception of the chemicals of a plant allows insects to identify plant location, availability and quality (Awmack and Leather, 2002; Nieminen et al., 2003). The preference for a determined plant (Singer, 2000) is an important step in the selection process and in the search for a source of food and a place for oviposition and refuge of herbivorous insects (Roitberg et al., 1999; West and Cunningham, 2002; Stamps and Linit, 2002; Nieminen et al., 2003).

\footnotetext{
${ }^{1}$ Universidad Nacional de San Antonio Abad del Cusco, Facultad de Ciencias Biológicas, Ciudad Universitaria. Av. de la Cultura 735, Cusco, Perú.

*Corresponding author (jfrancosta@gmail.com).

${ }^{2}$ Universidad de Concepción, Depto. de Botánica, Casilla 160-C, Concepción, Chile (egianoli@udec.cl).

Presented in XXVII Congreso Nacional de Entomología, Universidad Austral de Chile, Valdivia, Chile. 23-25 de noviembre de 2005.

Received: 20 September 2007.

Accepted: 23 November 2007.
}

Quinoa, Chenopodium quinoa Willd. (Chenopodiales: Chenopodiaceae), is a plant originated in the Andes. The grain is cultivated from sea level up to $4.500 \mathrm{~m}$ of altitude (Tapia, 1997). It has higher nutritive value than traditional cereals (Tapia, 1997), and is a promising cultivar for human consumption (National Research Council, 1989). Amarilla de Marangani and Blanca de Junín are commercial varieties grown in greater proportion in the Andes of southern Peru (Ormachea and Quispe, 1993). The differences among varieties of quinoa are found in the morphology, phenology and the chemical composition of the tissues (Bertero et al., 2004).

The moth Eurysacca melanocampta Meyrick (Lepidoptera: Gelechiidae) is the main pest in the cultivation of quinoa in the Andes in southern Peru (Delgado, 1989; Ormachea and Quispe, 1993; Rasmussen et al., 2000; 2001; Sequeiros, 2001; Rasmussen et al., 2003). The females lay their eggs on the leaves in the pre-flowering state when the grains are already developed (J.F. Costa, personal observation). The larvae of the first stages feed on the leaves and subsequently on the developing and mature grains (Ortíz, 1991; Ochoa, 1996; Melo, 2001; Rasmussen et al., 2003). Mating occurs over quinoa plants or over plants nearby (J.F. Costa, personal observation). 
The preference or acceptance of the female for a plant for feeding or as an adequate site for egg-laying is determined by the characteristics that the plants present; for example, quality and quantity of nutrients (nectar, pollen, aminoacides, among others), volatile compounds, secondary metabolites, phenology, tissue hardness and defense mechanisms (Joachim-Bravo et al., 2001; McNeely and Singer, 2001; Awmack and Leather, 2002; De Bruyn et al., 2002; Morewood et al., 2003; Mannion et al., 2003; Meiners et al., 2005; Coley et al., 2006). The selection of these characteristics allows the female to feed itself adequately or allows it to test for adequate conditions for the development of its offspring (Courtney and Kibota, 1990). To mate, the male must find a receptive adult female, for which it needs to use search strategies such as finding the host plant of the female (by chemical or visual means), seek sources of the interaction of odours of the female and host plants, or follow sources of odour (pheromones) in the search exclusively for the female.

The following objectives were proposed in a study of olfactory response: 1) to study the capacity of adults of $E$. melanocampta to search for quinoa plants using the plants as olfactory stimulus, 2 ) to determine the preference of females of E. melanocampta for odours derived from plants of two varieties of quinoa: Amarilla de Marangani and Blanca de Junín, and 3) to study the attraction of males to females of E. melanocampta and to host plants in olfactory assays.

\section{MATERIALS AND METHODS}

\section{Insects}

Larvae of E. melanocampta were collected from sheaths of quinoa with dry mature grains in fields of the quinoa var. Amarilla de Marangani in the locality of Ollantaytambo, Urubamba, Cusco (131' $\left.\mathrm{S}, 72^{\circ} 16^{\prime} \mathrm{W}\right)$. The plots for cultivating var. Amarilla de Marangani also used for growing corn (Zea mays L. var. Blanco Urubamba) as an associated cultivar. Approximately 600 larvae were collected in order to obtain the greatest number possible of adult moths. They were raised under laboratory conditions (temperature: $22 \pm 1^{\circ} \mathrm{C}$, relative humidity (HR): $60 \%$ ). The larvae feed on fresh leaves and dry grain of the quinoa var. Amarilla de Marangani. The sex of the specimens of E. melanocampta was identified in the chrysalis state and the chrysalides were isolated in $1 \mathrm{~L}$ plastic containers until the emergence of the adults (Ochoa, 1990). The adult males and females were maintained in isolation and fed with diluted honey (10\%) for one week until the beginning of the bioassays. The collection and raising of larvae, recovery of adults and olfactory bioassays were carried out between the months of April and August 2005.

\section{Varieties of quinoa}

Healthy plants of two varieties of quinoa were chosen: Amarilla de Marangani and Blanca de Junín, cultivated at the campus of the Universidad Nacional de San Antonio Abad del Cusco, Cusco, Peru. The plants were cultivated for 75 days and then transported in $3 \mathrm{~L}$ plastic containers to the greenhouse where they were kept until conducting the tests. The plants used in the tests had heights of $30 \mathrm{~cm}$ and were selected for having sheaths in development. The plants were replaced for each bioassay.

\section{Response of the female to odour stimuli}

The bioassays were made using a Y-olfactometer (Figure 1), based on the model of Eiras and Mafra-Neto (2001). The size and shape of the flexible glass containers were developed according to the size of the pots and plants to be used. The Y-olfactometer was developed taking into account that the interior needed to provide adequate space for adult E. melanocampta (long arm: 12 $\mathrm{cm}$, short arm: $6 \mathrm{~cm}$, side: $4 \mathrm{~cm}$ ). Two types of bioassays were made, the first consisted of the preference of adults between odour sources of a quinoa plant (var. Amarilla de Marangani) and distilled water as a control. In this assay adults were used without distinction of sex, chosen at random from a plastic container with 50 (males/females: $1 / 1)$. Some 20 bioassays were made. The objective of this assay was to demonstrate that adults (males and females) could identify and prefer the volatile compounds of their host plant (quinoa, indistinct of the variety) in the system of olfactory responses without the intervention of visual stimuli. Bioassays were made only with the var. Amarilla de Marangani given that the varieties of quinoa have the same chemical composition and differences lie in morphology, the time for phenological development and the concentration of these compounds in their tissues (Mastebroek et al., 2000; Bertero et al., 2004). The second bioassay consisted of the preference of females between two varieties of quinoa: Blanca de Junín and Amarilla de Marangani. Twenty five bioassays were made. In this second test only females were used, the objective was to demonstrate a preference between the two cultivars.

The bioassays were conducted in conditions of darkness at $18 \pm 1^{\circ} \mathrm{C}$ and $65 \% \mathrm{HR}$. The adults of $E$. melanocampta are more active nocturnally. The females feed and lay eggs at night and the males are more active in the search for females during the night hours, while during the day the adults take refuge among the leaves of the quinoa plants or plants associated with the cultivar. As well, some adults have been observed taking refuge among cracks in the soil (personal observations of the authors). Taking these observations into account, the above mentioned conditions were chosen in order not to alter the behavior and intensity of the activities of the adult 
E. melanocampta. Likewise, it was desired that the moths made their choices based solely on olfactory stimulus by avoiding visual stimulus in the assay.

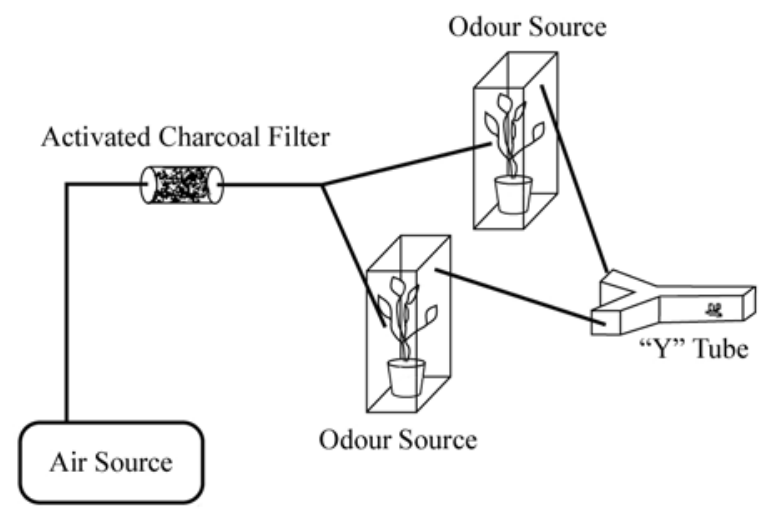

Figure 1. System of olfactory responses in a Y-olfactometer. The air is derived from the activated charcoal filter by a compressor using connecting hoses. The purified air flows towards flexible glass pots that contain whole plants or volatile compounds (odour sources). The air with volatile compounds is driven to each arm of the $Y$ olfactometer by little hoses. Eurysacca melanocampta adults were placed into the Y-olfactometer to conduct the bioassays.

Subsequently, the female was enclosed in the olfactometer and a flow of air of $260 \mathrm{~mL} \mathrm{~min}^{-1}$ was allowed in each of the arms of the olfactometer. Two odour stimuli were used, one in each arm of the olfactometer, coming from flexible glass containers with pots containing quinoa plants. The air was purified by passing it through a glass chamber containing activated carbon. The females used had emerged 1 week before from chrysalides. Females that showed greater activity were chosen for the assays. They were placed in the olfactometer $10 \mathrm{~min}$ before the beginning of each test to allow them to condition themselves to the space. The activity of each insect was observed for $10 \mathrm{~min}$ and the staying time in each arm was registered. The staying time was measured from the moment the insect approached the source of an odour in the decision-making area (bifurcation of the arms of the olfactometer). If an individual did not present activity or choice for one of the odour stimulus in a maximum period of $5 \mathrm{~min}$, it was replaced by another individual and the test began again. All of the specimens responded to some odour stimulus and none of the specimens were used a second time. The connecting hoses and the olfactometers were washed with detergent after the end of each test and dried in an isolated chamber to avoid impregnation of odours. None of the olfactometers were used in two tests consecutively.

\section{Response of the males to odour stimulus}

The evaluations were made with a 4 -arms olfactometer, which was prepared according to the description proposed by Pettersson (1970). The males used in the assay had emerged from chrysalids 1 week earlier. Four different odour stimuli were used, one for each of arms of the olfactometer: 1) Amarilla de Marangani plants, 2) Blanca de Junín plants, 3) Amarilla de Marangani plants plus four virgin females, and 4) four virgin females. A total of 25 assays were made, of which two specimens did not respond to any odour source. A different olfactometer and different hoses were used for each bioassay. The hoses for conducting the odour flow were located randomly with each of the arms of the olfactometer for each bioassay. The conditions were similar to those described in the bioassays with the Y-olfactometer. This test attempted to determine if the males identify and prefer the odour source of females alone (pheromones), submitting them to different odour sources simultaneously.

\section{Statistical analysis}

A paired Wilcoxon test (Zar, 1996) was conducted for the assays in the Y-olfactometer. With the assays with the 4-arms olfactometer the U Mann-Whitney test (Zar, 1996) was used for comparing the staying times among the four odour sources. The analysis was carried out with the Statistica $6.0^{\circledR}$ Program (StatSoft, 2001).

\section{RESULTS}

In the first bioassay with the Y-olfactometer, the staying time of the adult moths (males and females) was longer in the flow of odour from the quinoa plant (var. Amarilla de Marangani) than in that of distilled water ( $\mathrm{Z}$ $=3.92 ; \mathrm{P}<0.0001$ ) (Figure 2). In the second bioassay, females showed more preference for the var. Blanca de Junín, with a longer staying time in the flow of the odour from that variety than in that from the var. Amarilla de Marangani $(Z=2.08 ; P=0.037)$ (Figure 3).

In the 4-arms olfactometer bioassays, the males showed greater preference for the odour source of females alone. The staying time in the odour source of females was longer than in any other odour source. This preference was followed by the odour of plants of the var. Amarilla de Marangani (Figure 4). The least preferred was the combination of odour of females plus the var. Blanca de Junín (Figure 4). The U Mann Whitney rank-sum test of the two odour sources showed significance when comparing the preference between Blanca de Junín vs. females $\left(U=145.00 ; Z_{\text {adjusted }}=-2.625 ; \mathrm{P}=0.006\right)$, Amarilla de Marangani plus females vs. Amarilla de Marangani $\left(\mathrm{U}=177.00 ; Z_{\text {adjusted }}=-2.152 ; \mathrm{P}=0.031\right)$ and Amarilla de Marangani plus females vs. females $(U=132.00$; 
$\left.Z_{\text {adjusted }}=-3.143 ; P=0.002\right)$. There were no differences in preference among the other odour sources.

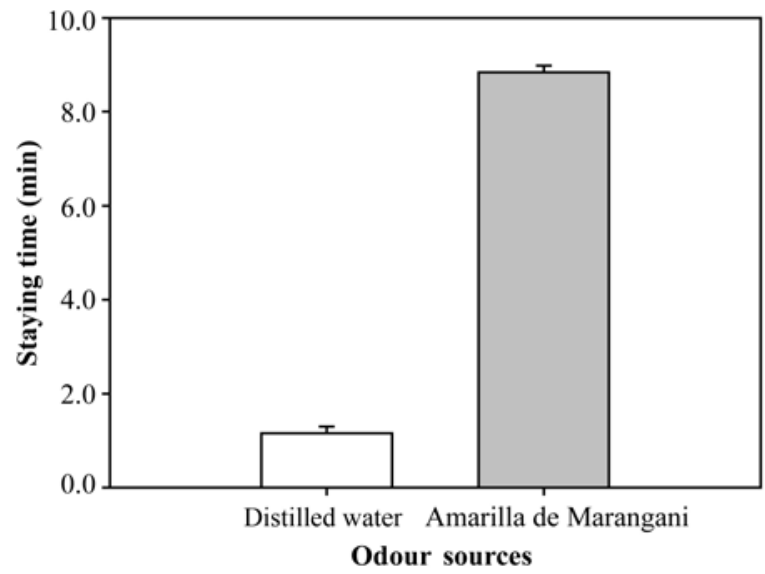

The bars represent the average staying time in the odour source. The lines over the bars represent the standard error.

Figure 2. Preference of Eurysacca melanocampta adults in a Y-olfactometer for two odour sources: Quinoa plants (Chenopodium quinoa) of Amarilla de Marangani variety were used vs. distilled water.

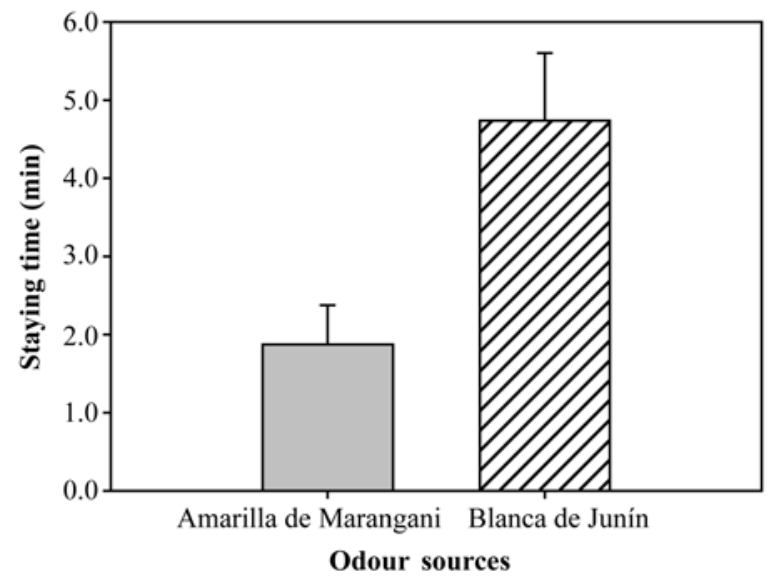

The bars represent the average staying time in the odour source. The lines over the bars represent the standard error.

Figure 3. Preference of Eurysacca melanocampta females in a Y-olfactometer for two odour sources: Amarilla de Marangani plants vs. Blanca de Junín plants.

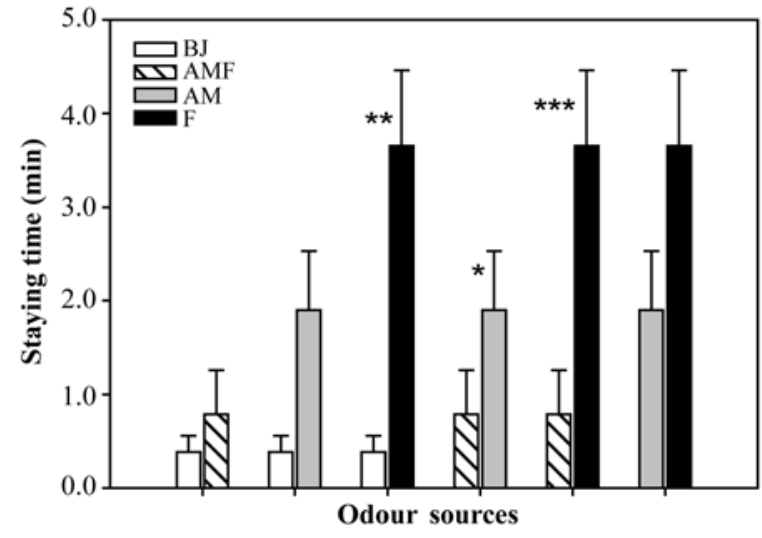

The bars represent the average staying time in the odour source. The lines over the bars represent the standard error.

$* \mathrm{P}<0.05 * * \mathrm{P}<0.01 \quad * * * \mathrm{P}<0.005$

Figure 4. Preference of Eurysacca melanocampta males for odour stimuli in a 4-arms olfactometer. BJ = Blanca de Junín plants; AMF = Amarilla de Marangani plants plus females; AM = Amarilla de Marangani plants; $\mathrm{F}=$ females. $\mathrm{U}$ Mann-Whitney tests were performed.

\section{DISCUSSION}

The adult quinoa moths rapidly chose the odour source of plants, between 5 and $15 \mathrm{~s}$ after the start of the tests (personal observations of the authors) and showed preference for the odour source of the quinoa plant (var. Amarilla de Marangani). Although the quinoa moth is not considered as an insect specific to the quinoa cultivar, this cultivar is the main plant host of this insect species (Rasmussen et al., 2003). E. melanocampta completes its biological cycle on quinoa plants and is registered as the main pest, with a close interaction between plant and insect that allows the adult E. melanocampta to rapidly identify the odour source of quinoa plants.

The females chose a host plant for egg-laying that provides the appropriate conditions for the development of their offspring (Courtney and Kibota, 1990). This choice is determined by the characteristics of the plants, such as: chemical defenses, physical defenses, maturity and hardness of tissue, among others (Awmack and Leather, 2002; Mannion et al., 2003; Meiners et al., 2005; Coley et al., 2006). The female E. melanocampta chose healthy pre-flowering quinoa plants in field conditions (J.F. Costa, personal observation). In the choice test (first bioassay with the Y-olfactometer), in darkness and with distilled water as a control, females chose the odour source of the quinoa plant. In this condition (darkness), the preference for a plant is based on olfactory stimulus and depends on the metabolites and chemical compounds emitted by the host plant (Coracini et al., 2004). 
In the second bioassay in the Y-olfactometer, the greater preference of females for the quinoa var. Blanca de Junín could be caused by the lower content of saponins in this variety. The var. Amarilla de Marangani is one of the cultivars with greater concentration of saponins in its tissue (Bertero et al., 2004). In general, females show a preference for laying their eggs in plants in which they developed (Courtney and Kibota, 1990) or plants that present better quality of nutrients that will allow for better development of their offspring (Janz and Nylin, 1997; Awmack and Leather, 2002; Morewood et al., 2003; Coley et al., 2006). In this manner, by choosing the variety with lower saponin content, when saponin has repellent or toxic effects on insects (Morrissey and Osbourn, 1999, cited by Francis et al., 2002), the female is providing an adequate food source for the development of its offspring. This fact explains the choice of females for quinoa plants of the var. Blanca de Junín, despite having been raised on plants of the var. Amarilla de Marangani. In this study, the females used in the bioassays were virgin, explaining only the preference and identification of their host plants. In this case, we determined the preference for acceptability of a plant (quinoa) for the females of E. melanocampta (Singer, 2000). It is necessary to carry out bioassays with egg-filled females that would allow for conclusive results about preference for this variety of quinoa for oviposition.

The emission of sexual pheromones of female moths can be detected by males at relatively long distances of between 250 and $1100 \mathrm{~m}$ (Sharov et al., 2002; White et al., 2003); and identification by male depends on chemical composition, environmental conditions and the concentrations in which the pheromones are emitted (Linn and Roelofs, 1989; Kawazu et al., 2001; Sharov et al., 2002; Botero-Garcés e Isaacs, 2004; Takanashi et al., 2006; Larraín et al., 2007). In the bioassays with the 4-arms olfactometer, males reacted more positively and with greater intensity to the stimulus of the odour of the females alone than to the source of odours of plants plus females or the odour of plants alone. This fact seems to indicate that the combination of the odour of plants plus females reduces the capacity of males to distinguish clearly the sexual pheromones produced by the females. In accordance with these results, we assume that the quinoa plants emits volatile compounds (alomons, Whitman et al., 1990) with a defense mechanism to avoid insect feeding or egg-laying on its tissue, and which in turn can cause a reduction in the concentration of sexual pheromones emitted by females, acting negatively on the search for females by males. Consequently, the exclusive search for females of E. melanocampta (mediated by pheromones) seems to be the mechanism used by males to locate females. Despite the results, we should taken into account that the males can identify and show similar preference between sexual pheromones and chemical compounds emitted by the host plant; for example: Coracini et al. (2004) showed this preference in olfactometric and field experiments with the apple moth, Cydia pomonella L. (Lepidoptera: Tortricidae). On the other hand, the females located on quinoa plants can emit a lower quantity of pheromones than the females that are alone (in the case of the bioassay) or on grass (in field conditions), and implies a reproductive advantage for females who rest on plants other than the host plant (quinoa). In either case, the host plant seems to play an important role in the moth-quinoa interaction, acting negatively on the search for females.

The response to olfactory stimulus in insect-plant interactions is an ecological process that is difficult to quantify and analyze. This fact is caused by the complex factors that interact in this relationship (Keller, 1999; Heard, 2000; van Klinken, 2000). Considering these facts, we should take into account that the bioassays were conducted under controlled conditions and that the variables that interact under conditions of cultivation (agro-ecosystems) are multiple (Singer and Lee, 2000). The bioassays were designed in an effort to explain in the best possible manner the mechanisms of attraction and preference in this system of study. However, if these observations are shown in agro-ecological conditions (Coracini et al., 2004), it could explain in a more precise manner the close ecological interaction between a plant of economic importance and its main pest.

\section{CONCLUSIONS}

In accordance with the proposed objectives, it was shown that adults of E. melanocampta could identify their host plant by olfactory means while in darkness. As well, the female shows greater preference for quinoa plants of the var. Blanca de Junín than for plants of the var. Amarilla de Marangani, possibly owing to a negative effect of the latter on the preference of the female. On the other hand, the male of E. melanocampta identifies and prefers the odour source of females alone and the interaction of plant plus female appears to diminish the capacity of males to search for females.

\section{ACKNOWLEDGEMENTS}

The present study was financed by the Project PER: 02, International Science Program (ISP), Uppsala University, Sweden. Magaly Aquino provided assistance in the field collection and raising in the laboratory. 


\section{RESUMEN}

Preferencia de la polilla de la quinua: Eurysacca melanocampta Meyrick (Lepidoptera: Gelechiidae) por dos variedades de quinua (Chenopodium quinoa Willd.) en ensayos de olfatometría. La atracción de insectos hacia las plantas es causada tanto por estímulos visuales como olfativos. La polilla de la quinua, Eurysacca melanocampta Meyrick (Lepidoptera: Gelechiidae), es la principal plaga en el cultivo de quinua, Chenopodium quinoa Willd. (Chenopodiales: Chenopodiaceae), en los Andes del sur peruano causando pérdidas en la producción de granos. El objetivo de este estudio fue evaluar las respuestas conductuales frente a estímulos olfativos de adultos de la polilla de la quinua. Específicamente, los objetivos del estudio fueron: 1) estudiar la capacidad de búsqueda de plantas de quinua de los adultos de E. melanocampta utilizando plantas como estímulos olfativos; 2) determinar la preferencia de hembras de E. melanocampta por olores derivados de plantas de dos variedades de quinua: Amarilla de Marangani y Blanca de Junín; y 3) estudiar la atracción de los machos hacia hembras de E. melanocampta y hacia las plantas hospederas en bioensayos de olfatometría. Los adultos eligieron fuentes de olor de las plantas de quinua en pruebas de elección cuando el control fue agua destilada $(\mathrm{P}<0,01)$. Las hembras fueron más atraídas hacia la var. Blanca de Junín que hacia la var. Amarilla de Marangani $(\mathrm{P}<0,05)$. Los machos fueron más atraídos por el olor de hembras que por los compuestos volátiles de las plantas (ambas variedades) o por el olor derivado de hembras más plantas. El nivel de atracción de los machos hacia las hembras fue negativamente afectado por la presencia de las plantas de quinua.

Palabras clave: atracción, Chenopodiaceae, Gelechiidae, búsqueda, olfatometría, quinua.

\section{LITERATURE CITED}

Awmack, C.S., and S.R. Leather. 2002. Host plant quality and fecundity in herbivorous insects. Annu. Rev. Entomol. 47:817-844.

Bernays, E.A., and R.F. Chapman. 1994. Host-plant selection by phytophagous insects. 312 p. Chapman $\&$ Hall, New York, USA.

Bertero, H.D., A.J. De La Vega, G. Correa, S.E. Jacobsen, and A. Mujica. 2004. Genotype and genotype-byenvironment interaction effects for grain yield and grain size of quinoa (Chenopodium quinoa Willd.) as revealed by pattern analysis of international multienvironment trials. Field Crops Res. 89:299-318.
Botero-Garcés, N., and R. Isaacs. 2004. Movement of the grape berry moth, Endopiza viteana: displacement distance and direction. Phisiol. Entomol. 29(5):443452.

Coley, P.D., M.L. Bateman, and T.A. Cursar. 2006. The effects of plant quality on caterpillar growth and defense against natural enemies. Oikos 115(2):219228.

Coracini, M., M. Bengtsson, I. Liblikas, and P. Witzgal. 2004. Attraction of codling moth males to apple volatiles. Entomol. Exp. Appl. 110:1-10.

Courtney, S.P., and T.T. Kibota. 1990. Mother doesn't know best: selection of hosts by ovipositing insects. p. 161-188. In Bernays, E.A. (ed.) Insect-plant interactions. CRC Press, Boca Ratón, Florida, USA.

Delgado, P.M. 1989. Determinación taxonómica y porcentaje de parasitismo de insectos benéficos sobre Eurysacca melanocampta Meyrick "Kcona Kcona" en quinua. 46 p. Tesis Biólogo. Universidad Nacional del Altiplano, Facultad de Ciencias Biológicas y Agrarias, Puno, Perú.

De Bruyn, L., Scheirs, J., and R. Verhagen. 2002. Nutrient stress, host plant quality and herbivore performance of a leaf-mining fly on grass. Oecologia 130:594-599.

Eiras, A.E., e A. Mafra-Neto. 2001. Olfatometria aplicada ao estudo do comportamento de insetos. p. 27-40. In Vilela, E.F. e T.M.C. Della Lucia (eds.) Feromônios de insetos. 2nd ed. Holos, Ribeirão Preto, Brasil.

Francis, G., Z. Kerem, H.P.S. Makkar, and K. Becker. 2002. The biological action of saponins in animal systems: a review. Br. J. Nutr. 88:587-605.

Heard, T.A. 2000. Concepts in insect host-plant selection behaviour and their application to host specificity testing. p. 1-10. In Van Driesche, R.G., T. Heard, A.S. McClay, and R. Reardon (eds.) Proceedings: Host Specificity Testing of Exotic Arthropod Biological Agents: The Biological Basis for Improvement in Safety. X International Symposium on Biological Control of Weeds, Montana, USA. 4-14 July 1999. Bozeman, United States Department of Agriculture (USDA), Forest Service Bulletin, FHTET-99-1, Morgantown, West Virginia, USA.

Janz, N., and R. Nylin. 1997. The role of female search behaviour in determining host plant range in plant feeding insects: a test of the information processing hypothesis. Proc. R. Soc. London, Ser. B 264:701707.

Joachim-Bravo, I.S., O.A. Fernandes, S.A. De Bortoli, and F.S. Zucoloto. 2001. Oviposition behavior of Ceratitis capitata Wiedemann (Diptera: Tephritidae): association between oviposition preference and larval performance in individual females. Neotrop. Entomol. 30(4):559-564. 
Kawazu, K., O. Setokuchi, K. Kohno, K. Takahashi, Y. Yoshiyasu, and S. Tatsuki. 2001. Sex pheromone of the rice leaffolder moth, Cnaphalocrocis medinalis (Lepidoptera: Crambidae); synthetic Indian and Philippine blends are not attractive to male $C$. medinalis, but are attractive to C. pilosa in the SouthWestern islands in Japan. Appl. Entomol. Zool. 36(4):471-474.

Keller, M.A. 1999. Understandinghostselectionbehaviour: the key to more effective host specificity testing. p. 84-92. In Whithers, T.M., L. Barton-Browne, and J. Stanley (eds.) Host specificity testing in Australasia: Towards improved assays for biological control. Scientific Publishing, Queensland Department of Natural Resources, Brisbane, Queensland, Australia.

Larraín, P., M. Guillon, J. Kalazich, F. Graña, and C. Vásquez. 2007. Efficacy of different rates of sexual pheromone of Phthorimaea operculella (Zeller) (Lepidoptera: Gelechiidae) in males of potato tuber moth captures. Agric. Téc. (Chile) 67:431-436.

Linn, C.E., and W.L. Roelofs. 1989. Response specificity of male moths to multicomponent pheromones. Chemical Senses 14:421-437.

Mannion, C., A. Hunsberger, J. Peña, and L. Osborne. 2003. Oviposition and larval survival of Diaprepes abbreviatus (Coleoptera: Curculionidae) on select host plants. Fla. Entomol. 86:165-173.

McNeely, C., and M.C. Singer. 2001. Contrasting the roles of learning in butterflies foraging for nectar and oviposition sites. Anim. Behav. 61:1-7.

Mastebroek, D., H. Limburg, T. Gilles, and H.J.P. Marvin. 2000. Occurrence of sapogenins in leaves and seeds of quinoa (Chenopodium quinoa Willd). J. Sci. Food. Agric. 80:152-156.

Meiners, T., N.K. Hacker, and M. Hilker. 2005. Response of the elm leaf beetle to host plant induced by oviposition and feeding: the infestation rate matters. Entomol. Exp. Appl. 115:171-176.

Melo, L.A. 2001. Insectos asociados al cultivo de quinua en Cusco. 51 p. Tesis Bachiller en Ciencias Biológicas. Universidad Nacional de San Antonio Abad del Cusco, Facultad de Ciencias Biológicas, Cusco, Perú.

Morewood, W.D., P.R. Neiner, J.R. McNeil, J.C. Sellmer, and K. Hoover. 2003. Oviposition preference and larval performance of Anoplophora glabripennis (Coleoptera: Cerambycidae) in four eastern North American hardwood tree species. Environ. Entomol. 32:1028-1034.

National Research Council. 1989. Lost crops of the Incas: Little known plants of the Andes with promise for worldwide cultivation. p. 148-161. Natl. Acad. Press, Washington D.C., USA.
Nieminen, M., J. Suomi, S. Van Nouhuys, P. Sauri, and M.L. Riekkola. 2003. Effect of iridoid glycoside content on oviposition host plant choice and parasitism in a specialist herbivore. J. Chem. Ecol. 29(4):823844.

Ochoa, M.R. 1990. Ciclo biológico de la polilla de la quinua en condiciones de laboratorio. $60 \mathrm{p}$. Tesis Biólogo. Universidad Nacional de San Antonio Abad del Cusco, Facultad de Ciencias Biológicas, Cusco, Perú.

Ochoa, J.A. 1996. Principales plagas y sus enemigos naturales en el cultivo de quinua en la localidad de Huacarpay, Cusco. 45 p. Tesis Bachiller en Ciencias Biológicas. Universidad Nacional de San Antonio Abad del Cusco, Facultad de Ciencias Biológicas, Cusco, Perú.

Ormachea, E., y D. Quispe. 1993. Evaluación de parasitoides de la "polilla de la quinua" Eurysacca melanocampta, en el Cusco. In XXXV Convención Nacional de Entomología, Arequipa, Perú. 11-14 noviembre 1993. Sociedad Entomológica del Perú, Lima, Perú.

Ortíz, R. 1991. Pérdidas ocasionadas por insectos plaga en cultivos andinos: campañas 1990-1991. 10 p. Convenio Facultad de Ciencias Agrarias, Universidad Nacional del Altiplano (FCA/UNA). Proyecto Programa Interinstitucional de Waru Waru (PIWA), Puno, Perú.

Pettersson, J. 1970. Studies on Rhopalosiphum padi (L.): laboratory studies on olfactometric responses to winter host Prunus padus L. Lantbrukshoegsk. Ann. 36:381-399.

Rasmussen, C., S.E. Jacobsen, y A. Lagnaoui. 2000. Las polillas de la quinua. Especies en Perú de Eurysacca (Lepidoptera: Gelechiidae) en la quinua (Chenopodium quinoa Willdenow). In XLII Convención Nacional de Entomología, Tarapoto, Perú. 22-26 de octubre de 2000. Sociedad Entomológica del Perú, Lima, Perú.

Rasmussen, C., S.E. Jacobsen, y A. Lagnaoui. 2001. Las polillas de la quinua (Chenopodium quinoa Willd.) en el Perú: Eurysacca (Lepidopt.: Gelechiidae). Rev. Per. Entomol. 42:57-59.

Rasmussen, C., A. Lagnaoui, and P. Esbjerg. 2003. Advances in the knowledge of quinoa pests. Food Rev. Int. 19:61-75.

Roitberg, B.D., I.C. Robertson, and J.G.A. Tyerman. 1999. Vive la variance: a functional oviposition theory for insect herbivores. Entomol. Exp. Appl. 91:187-194.

Sequeiros, P.A. 2001. Fluctuación poblacional de plagas insectiles en quinua y sus controladores naturales. $82 \mathrm{p}$. Tesis Biólogo. Universidad Nacional de San Antonio Abad del Cusco, Facultad de Ciencias Biológicas, Cusco, Perú. 
Sharov, A.A., K.W. Thorpe, and K. Tcheslavskaia. 2002. Effect of synthetic pheromone on gypsy moth (Lepidoptera: Lymantriidae) trap catch and mating success beyond treated areas. Environ. Entomol. 31:1119-1127.

Singer, M.C. 2000. Reducing ambiguity in describing plant-insect interactions: "preference", "acceptability" and "electivity". Ecol. Lett. 3:159-162.

Singer, M.C., and J.R. Lee. 2000. Discrimination within and between host species by a butterfly: implications for design of preference experiments. Ecol. Lett. 3:101-105.

Stamps, W.T., and M.J. Linit. 2002. Oviposition choice by the black walnut curculio (Coleoptera: Curculionidae): A ten-year study. Environ. Entomol. 31:281-284.

StatSoft. 2001. Statistica (data analysis software system), version 6. StatSoft Inc., Tulsa, Oklahoma, USA. Available at http://www.statsoft.com.

Takanashi, T., I. Yukio, P. Anderson, Y. Huang, C. Löfstedt, S. Tatsuki, and B.S. Hansson. 2006. Unusual response characteristics of pheromone-specific olfactory receptor neurons in the Asian corn borer moth, Ostrinia furnacalis. J. Exp. Biol. 209:4946-4956.

Tapia, M. 1997. Cultivos andinos subexplotados y su aporte a la alimentación. 2da. ed. 273 p. FAO, Oficina Regional para América Latina y el Caribe, Santiago, Chile. van Klinken, R.D. 2000. Host specificity testing: why do we do it and how we can do it better. p. 54-68. In Van Driesche, R.G., T. Heard, A.S. McClay, and R. Reardon (eds.) Proceedings: Host Specificity Testing of Exotic Arthropod Biological Agents: The Biological Basis for Improvement in Safety. X International Symposium on Biological Control of Weeds, Montana, USA. 4-14 July 1999. Bozeman, United States Department of Agriculture (USDA), Forest Service Bulletin, FHTET-99-1, Morgantown, West Virginia, USA.

West, S.A., and J.P. Cunningham. 2002. A general model for host plant selection in phytophagous insects. J. Theor. Biol. 214:499-513.

White, M.A., Host, G.E., and D.R. Benson. 2003. Northeastern Minnesota trapping study: Effects of temperature and trap density on male gypsy moth recapture and flight patterns. Forest Insect Dis. Newsl. November 2003. Minnesota Department of Natural Resources, St. Paul, Minnesota, USA. Available at http://www.dnr.state.mn.us/fid/nov03/research.html (Accessed July 2007).

Whitman, D.W., M.S. Blum, and D.W. Alsop. 1990. Allomones: chemicals for defense. p. 289-351. In Evans, D.L., and J.O. Schmidt (eds.) Insect defenses: adaptive mechanisms and strategies of prey and predators. State University of New York Press, Albany, New York, USA.

Zar, J.H. 1996. Biostatistical analysis. 662 p. PrenticeHall, Upper Saddle River, New Jersey, USA. 